\title{
Humour as political aesthetics in street protests during the political Ice Age ${ }^{1}$
}

\author{
Tijen Tunalı \\ AIAS-Aarhus University, Denmark \\ tijen.tunali@aias.au.dk
}

\begin{abstract}
This article analyses humour as a part of carnival aesthetics in urban social movements. It regards humour's place in street protests as an aesthetic experience that brings forth an interplay of joy, imagination and freedom. Drawing from social movement theory regarding collective identity and collectivism, aesthetic theory and Mikhail Bakhtin's theory of carnivalesque, this paper examines the link between humour and carnival aesthetics in recent social movements. It argues that carnival laughter initiates a process of symbiosis that opens relationships with others and allows recognition of democratic diversity, aesthetic sensibility and political dignityessential for the reconstruction of a new space that is resistant to the politically imposed world crisis. It asks: could humour be one of the social catalysts we need during the authoritarian turn in a political Ice Age instigated by conservative populism? Drawing on examples from the Gezi Movement in Turkey in 2013, the article demonstrates how humour is not just a tool to consolidate solidarities but a definitive aesthetic experience that, in the context of the street protests, becomes the antidote to hegemonic-sense-making mechanisms and the greyness of our collective thinking.
\end{abstract}

Keywords: humour, carnival laughter, social movements, civil resistance, aesthetic activism.

\section{Introduction}

Since the anti-globalisation (or alter-globalisation) movement, urban social uprisings advocate for radical change in a pluralistic sense, reject a singular political identity and operate with a vision of revolutions that is beyond the classical Marxist discourse of class contradictions. As neoliberalism promoted itself as an unchallengeable force with no alternatives, various mobilisations against it, all around the world, have engaged resistance through culture to spur action toward systemic change. The visible difference between these movements and those of the twentieth century has been the enhanced aesthetic sphere. Especially, humour has had a significant place in social resistance aesthetics. It is commonly known that humour gives

\footnotetext{
${ }^{1}$ In writing this article, I depended on my field notes and my participant observations in the occupation of Gezi Park in Istanbul and the occupation of Gündoğdu Square in Izmir May 27-June 15, 2013. During this time and in the fall of 2013, I also compiled 23 semi-structured narrative interviews with protestors from different political backgrounds.
} 
momentum to protests by strengthening morale and forging a collective identity and thus, ensuring the continuity of the movement. However, such humour, if identified generally as "political humour", would include any humorous text, act or image that deals with political issues, people, events, processes, or institutions. This paper will not argue about the politics of the so-called political humour, but will rather present the social politicity of humour as an aesthetic experience (Gordon 2012; Young 2017).

By integrating aesthetic theory, carnival theory and humour theory into scholarly research, social media depictions and participant observation, this paper illustrates how humour in social protests manifests itself as an embodied consciousness - an acute perceptual awareness that resonates with political subjectivity. Such awareness is the central aspect of the aesthetic. The aesthetic experience of laughing and joy that humour offers is not necessarily temporal and valued for its own sake. Humour could have long-term effects just like experiencing a piece of art, a building, a landscape, a situation or an event. Especially, satirical activism arguably plays a key role in how we perceive class conflicts, politics and the political process (Haugerud 2012, 2013). Humour theorist John Morreall writes that, "humour is an aesthetic experience that involves the use of the imagination and it is accompanied by a sense of freedom" (Morreall 1981: 57). The experience of imagination, joy, and freedom, of course not, do make humour an aesthetic subversion of the political; but such a perspective offers a theoretical lens through which we can think of humour in the sense of the carnival being a valuable force of resistance that merges the political and the aesthetic (See Bakhtin 1984; Bey 1985; Vaneigem 1994). This paper proposes that humour is an aesthetic experience that has the power to reconfigure established sensibilities, norms and beliefs among those protestors on the streets and squares.

The scholars of communication and media studies, as well as linguists and ethnologists, have observed humour and satire in the recent social movements and protests from the perspective of a "language of resistance" (Dağtaş 2006; Emre et al. 2013; Haugerud 2013; Flamenbaum 2014). The use of social media inevitably helps political humour become an effective tactic as they can spread it quickly on a mass scale with less censorship than undeviating political arguments. While the social media platforms help intensify communication ties among the protestors through humorous language and visuality, thus forging a collective identity as argued, this is only one dimension of the social use of the satire and laughter in social movements. In this paper, focusing on the example of the Gezi Uprising in Turkey, I will discuss humour in the context of the recent social movements, and I will explain this collective aesthetic experience with the concept of carnival aesthetics. I will do that by examining philosopher and literary critic Bakhtin's theory of carnival and joy (Bakhtin 1984) as the basis for cultural and political radicalism. I will argue that humour and laughter are an integral part of carnival aesthetics that initiates a process of symbiosis and opens relationships with others and that allows recognition of democratic diversity, aesthetic sensibility and political dignity - essential for the reconstruction of a new space of resistance to the politically imposed world crisis. And I ask: Can humour be one of the social catalysts we need during the authoritarian turn in our political Ice Age that is instigated by conservative populism?

The known social outcomes of political humour and satire are social criticism, exposed truths, and impunity in the face of violence. It is also commonly known that in social protests, humour functions as a morale booster and keeps the protest community together. Sociologist Sørensen, who studied humour in the Serbian Otpor movement as a strategy for non-violent resistance, lists three important factors for that: 1) humour that provokes, mocks, or ridicules escalates the conflict and puts pressure on the oppressor, (2) it reduces fear within the resistance movement, (3) it reduces the oppressors' options for reacting (Sørensen 2008: 180). In addition to these, humour and laughter make the rebellion more enjoyable, inclusive, joyful, irresistible and resilient (Mersal 2011). This paper adds an aesthetic dimension to these effects to argue that during social protests, collectively experienced humour allows for an alternative experience to the quotidian life. The use of costumes and masks, the concept of the upside-down world, the comic transgression, satire 
and laughter disturb the submissiveness of everyday life. The interactions between people enjoying humorous art, performances, theatrical pieces, tactical interventions, graffiti, caricatures, posters and social media memes together have a bearing on the experience itself, which becomes a perpetual awareness. Can this awareness be channelled into creating alternative political subjectivities? My goal is to start to bring two conversations together, one that is taking place on the political role of aesthetics in social movements and the other, the social role of humour in protests as a collective and subversive experience.

\section{Carnival laughter during the political Ice Age}

In Rabelais and His World, Bakhtin analyses the social function of the carnivalesque in the work of the sixteenth-century century writer François Rabelais and regards the Medieval carnival as a popular expression of subversion, a "world turned inside out" in which people can attack, resist, and invert the systems of power that structure their everyday existence. He writes: "They offered a completely different, nonofficial, extra-ecclesiastical and extra-political aspect of the world of man, and of human relations; they built a second world and a second life outside officialdom" (Bakhtin 1984: 5-6). For Bakhtin, the work of Rabelais presents a key to the people's creation of a second life, organised on the base of laughter (Bakhtin 1984: 8). He writes:

The Renaissance conception of laughter can be roughly described as follows: Laughter has a deep philosophical meaning, it is one of the essential forms of the truth concerning the world as a whole, concerning history and man; it is a peculiar point of view relative to the world; the world is seen anew, no less (and perhaps more) profoundly than when seen from the serious standpoint. Therefore, laughter is just as admissible in great literature, posing universal problems, as seriousness. Certain essential aspects of the world are accessible only to laughter (Bakhtin 1984: 66).

The way the contemporary meaning of festive humour connects to the Medieval festivities is not historical discord, but a recognition of the essential need of the masses to become active communities. Bakhtin notes: "To ignore or underestimate the laughing people of the Middle Ages also distorts the picture of European culture's historic development" (Bakhtin 1984: 6). Bakhtin's statement pertains to the political role of laughter in culture but, as I will argue in this paper, this role transcends European culture and becomes universal due to the global projection of the urban uprisings and social movements. Following the translation of Bakhtin into English in 1968, carnivalesque elements have been more popularly integrated as an aesthetic element into those protests seeking intense participation. In Bakhtin's theory of the carnival, life steps out of its routine and sanctifies a different time, for a short period, but the shortness of this time enhances the fantastic nature and utopian radicalism of the carnivalesque (Bakhtin 2002: 109). According to Bakhtin, during carnivals, people are freed from the accustomed daily life relations, generally accepted norms, and common beliefs. This upside-down world of the carnival gives people imaginative and discursive freedom (Scott 1990; 172-182).

The understanding of carnival laughter as an aesthetical experience allows us to pay attention to not only its communicative and subversive qualities, but also its affective, creative and regenerative potential-an essential element for the continuation of the protests. Perhaps most importantly, the collective aesthetic experience of the carnival creates new modes of sense perception that allow a type of cognitive and sensory liberation (Vaneigem 1994). This is also paraphrased as creating unexpected relations of resilience and solidarity, often referred to by academic activists such as John Holloway, David Graeber, and Gavin Grindon, to name a few (Holloway 2002; Grindon 2004; Graeber 2010). The symbolism of the aesthetic experience of the uprisings is perhaps best explained by the words of Subcomandante Marcos of the Zapatistas in Chiapas Mexico, who rose up against neoliberal expansion in 1994: "The Revolution, in general, 
is no longer imagined according to socialist patterns of realism, that is, as men and women stoically marching behind a red, waving flag towards a luminous future. Rather, it has become a sort of carnival" (Notes from Nowhere 2003: 176). Here, the carnival aesthetic both points to the aesthetic sensibility of the revolution-in-the-making and to the practice of politics.

Cultural interventions in the physical and virtual space of the resistance have emerged as a main visible character of the local and global movements since 1999 (Grindon 2006; Graeber 2010; Thomson 2010). The Anti-Globalisation movement (Global Justice Movement) organisers and participants used the term carnival to describe the ambience and activism of the flamboyant costumes, clowns, dance, puppets, tricksterism, samba bands and other musical groupings (Bogad 2010). Since then, this carnivalesque aesthetic has been a usual and common sight in the protests around the world. Perhaps the most vivid memory of the Reclaim the Streets protests in 1996 in London was the carnivalesque action groups such as Pink and Silver bloc, Clandestine Insurgent Rebel Clown Army (C.I.R.C.A) and Tute Bianche, who used the power of carnival costumes and funny masks to confuse the police and avoid violent confrontations on the frontlines. Other antiglobalisation protests around Europe followed in the same vein. Finally, after Revolutionary Anarchist Clown Bloc made its appearance in Philadelphia in 2000 with their unicycles, squeaky mallets, and big shoes and confused the police, the humorous carnival attire has become a visual mark of today's young activist generation. Since then, clowns face to face with police or giving police flowers have been a popular sight recorded by photojournalists. Often, giant puppets, effigies and people in all sorts of characters join this carnival. Drums and other musical instruments are passed from one activist to the next because the act is meant to be that of collective imagination and participation. Certainly, these are practical acts to confuse the police and create a psychological wall in the face of police violence. Graeber emphasises the transgressive character of the visual carnival of millennial protests:

In fact, there's usually no clear line between puppets, costumes, banners and symbols, and simple props. Everything is designed to overlap and reinforce each other. Puppets tend to be surrounded by a much larger 'carnival bloc,' replete with clowns, stilt-walkers, jugglers, fire-breathers, unicyclists, Radical Cheerleaders, costumed kick-lines or often, entire marching bands-such as the Infernal Noise Brigade of the Bay Area or Hungry March Band in New York - that usually specialise in klezmer or circus music, in addition to the ubiquitous drums and whistles. The circus metaphor seems to sit particularly well with anarchists, presumably because circuses are collections of extreme individuals (one cannot get much more individualistic than a collection of circus freaks) nonetheless engaged in a purely cooperative enterprise that also involves transgressing ordinary boundaries (Graeber 2010: $384)$.

Humour is an essential element of the collective creativity in protests that acts as a universal and effective tool to do political culture jamming. When the creative engagement of the protestors is influential and acted upon, such as satirical street art, posters on walls, and the memes, caricatures, and messages circulating on social media, protestors are more motivated to be involved and stay involved politically. This is incessant today with the global Extinction Rebellion movement. During the protests in London in the first two weeks of October 2019, people jumping around in Kangaroo costumes and a giant pink octopus named Jeanne-Luc, dragged by Police around Trafalgar Square, were two ludicrous images that prompted humour among the protestors. Although some commentators in mainstream media regarded this scenery as "a carnival for middle classes who love to dress up as activists", clearly, such acts during protests create a psychological wall in the face of police violence and strengthen the sense of community and solidarity (Furedi 2019). The youth coordinator of XR activist, Savanah Lovelock, said to a Guardian reporter: "Rebellion is not just going on the street and getting arrested, it is also rebelling against a system that makes us lonely and have no purpose. It is about creating those communities where people are held in their grief and their terror of what is going on" (Guardian 2019). The 
communities of rebellion all around the world cope with such terror and grief with a humorous spirit (Dağtaş 2006; Emre et al. 2013; Tunali 2018).

The humour in protests is about more than creating joy and community spirit: it opens a space of critique in the usual order of things. During the occupation of Zuccotti park in 2011, elegantly attired demonstrators calling themselves "Multi-Millionaires for Mitt" waved placards declaring "Corporations Are People Too!" and chanted "We're here, we're rich, get used to it" (Goodwin 2012). An activist group hitherto known as Billionaires for Bush appeared in Liberty plaza wearing tiaras, evening gowns and tuxedos as Billionaires for the One Percent and Billionaires for Plutocracy, with banners saying, "It's a Class War, and We're Winning!" and "Buy Your Own Democracy!" The satire, which twisted the protestor's claim to be identified as the $99 \%$, pointed to the US congressional restraints and public disclosure mandates for corporate political contributions in early 2012. Writing on the Billionaire activists, anthropologist Angelique Haugerud comments that the interventions pointing to these developments were well-targeted because "These limitations opened political space not only for Occupy Wall Street's direct democracy and direct action but also for parodies of the election system's financing rules" (Haugerud 2012: 151). Also observed in the uprisings following the Occupy Wall Street Movement in Tunisia (2011), Egypt (2011), Spain (2011), Greece (2011), and Turkey (2013), humorous activism interrogates the legitimacy of government policies and paves the way for the delegitimation of the ruling elites' hegemonic discourse.

The unpredictable humour and satire have been one of the poignant visual characteristics of the recent urban social movements and their carnivalesque atmosphere. The use of costumes and masks, fluid identities and characters, the comic violence, the satire and laughter connect the concept of the upside-down world to all other subversive acts of the carnivalesque. Bakhtin's argument that "laughter presents an element of victory not only over supernatural awe, over the sacred, over death; it also means the defeat of power, of earthly kings, of the earthly upper classes, of all that oppresses and restricts" (Bakhtin 1984: 92) is not to be taken literally. Neither should such carnival laughter be understood as a spectacle. Bakhtin's upside-down world perspective of humour in the medieval carnival, which mocks the grotesque elements of authority and crowns the village idiot as a king, offers a critical perspective for an alternative world, rather than establishing the carnival as a revolutionary event (Grindon 2004: 151). In our daily life, we already know that the foolish world of humour creates a humane bond between people. From the critical lens Bakhtin offers, we should try to understand how humour acts as a social force that allows an unusual perspective to enter socio-political discourse and how we could imagine "the world turned upside down" as an actuality. Comparing European protests of different periods, Marjolein 't Hart also brings forth the much-revered perspective of Bakhtin:

During carnivals and similar festive periods former ranks and hierarchies disappeared. All participants to the carnival were considered equal and free and familiar contacts were allowed between different social classes and positions. These ritual settings stressed the all-human, all-joyous characteristics of life and opened the way for playful and undefined relationships" (Hart 2007: 4).

She adds: "During such events, political protest was possible, as long as it was done by joking" (Hart 2007: 4). Hence, social protests, with all their carnivalesque elements, are still not carnivals. Every protestor knows that police clashes could happen any time and they could be arrested or hurt, which we have witnessed in the latest urban social movements. Since 1999, when Reclaim the Streets (RTS) took place in London and was called "Carnival Against Capital", phrases such as the "carnival of resistance" and "carnival of the oppressed" have been used to describe both the aesthetic and political dimension of the protests. In a book that compiles activist accounts from all over the world on anti-globalization protests, the activists declare: "We attempt, through our aesthetic and our fierce commitment to the politics of joy and desire, to create a space 
of carnival where all rules are broken and anything is possible. We seek to dissolve all barriers between art and politics, participants and spectators, dream and action" (Notes from Nowhere 2003: 224). In their book Multitude (2004), Hardt \& Negri reference Bakhtin's notion of the carnival in their added section titled "Carnival and Movement", and write that the global protests against capitalism are carnivalesque, "not only in their atmosphere [but] also in their organisation" (Hardt \& Negri 2004: 211).

Terry Eagleton has infamously argued that such carnivals of resistance are a type of licence d'affaire institutionalised by elites as a safety valve or permissible rupture in hegemony for social release and better political control (Eagleton 2009 [1981]). Gavin Grindon aptly points out that the safety valve theory regards society as a closed system. He comments: "This is not only misleading but denies the working class their proper role in the battle against capital" (Grindon 2004: 153). Indeed, the temporary suspension of ordinary life, upside-down order of power, undefined relationships and identities in carnival provide instances for redefining meanings and social order. Activist academic John Holloway interprets carnival laughter as a crack in capitalist relations and explains it as such: "This is a time too in which laughter breaks through the seriousness of the business of domination and submission, not individual laughter but a collective laughter that opens towards another world" (Holloway 2010:31). Lane Bruner concludes that the carnivalesque moments could be temporary and spectacular, but they are capable of serving a much greater purpose; "allowing subjects to enter a liminal realm of freedom and in so doing create a space for critique that would otherwise not be possible in "normal' society" (Bruner 2005:140). I base my arguments on these perspectives that articulate carnival aesthetics beyond a transient form of engagement and a spectacularising force and emphasize the collective laughter as an important tool in the process of the re-composition of the protesting crowds.

Humour research has demonstrated that political humour can increase the salience of certain issues or constructs in the minds of the audience (Moy et al. 2006). Could collective laughter in protests, when perceived aesthetically, have a transformative effect on individuals? For example, could it change how they perceive others and how they perceive the world around them? In contemporary social movements, people come together from different political and social spheres, often with important ideological and social differences. Laughing together with strangers in an environment that could be life-threatening allows individuals to transgress the borders of identity, ethnicity, and sexuality. Collective laughter and carnivalesque joy initiate a process of symbiosis that creates open relationships with others and allows recognition of diversity and a collective sensibility of time and place. Bakhtin writes on this sociality of the carnival:

However, medieval laughter is not a subjective, individual and biological consciousness of the uninterrupted flow of time. It is the social consciousness of all the people. Man experiences this flow of time in the festive marketplace, in the carnival crowd, as he comes into contact with other bodies of varying age and social caste (Bakhtin 1984: 92).

In their "declaration" on the global uprising of the multitude, Hardt \& Negri emphasised that, "participants experienced the power of creating new political affects through being together" (Hardt \& Negri 2012: "Opening").

This coming together is especially a needed articulation against the dangerous ethnic, social and cultural polarisation in Turkish society. In the following pages, I will argue that this constituted an important dimension of the social politicity of the Gezi Uprising in Turkey. Humour worked to overcome fear against police brutality but perhaps more importantly, it worked for affirming comradeship in the face of the political authoritarianism that survives on perpetuating polarisation and enmity in Turkey. I will first lay out the cultural and political authoritarianism as the backdrop to the Gezi Uprising. Within the visual context of the Gezi Uprising, I will then state that the carnival laughter, as an aesthetic experience, facilitates dialogue 
among the participants and the broader public; it enables a collective identity and solidarity; it creates social bonds and transforms people from hopeless submission to a joyful readiness to struggle for change. The evidence provided in this essay was gathered from Gezi Park, the Taksim area in Istanbul, as well as from social media posts during the street protest and the occupation of Gezi Park.

\section{The joy of dignity against authoritarianism}

The Gezi uprising in Turkey was the result of the swift and heavy-handed neoliberal restructuring of the economy as well as the social make-up since the Justice and Development Party (Adalet ve Kalkınma Partisi, AKP) came to power in 2002. With AKP's neoliberal programme and conservative Islamic agenda, middle class and lower-class religious conservatives, who had been excluded from secular modernisation processes since the foundation of the Turkish Republic in 1923, suddenly benefited from the drastic privatisation campaign (Soner 2020). The popular segments of the society entered into the post-modernization of culture (especially with immigration from rural Turkey to the economic centres), which created a new system of values (Taş 2015). Those values included a new lifestyle-new kinds of music, architecture, and fashion - that eventually constituted a new post-modern Turkish identity that had been decolonized from Western influences. The cultural politics of the new political elite of Erdoğan's AKP party that came in power flourished in this environment. What looked like a progressive development in culture, for the processes of democratization, eventually turned into an instrument of fascism (Kahraman 2007: 105). Erdoğan and his pro-Islam conservative party seized the opportunity very well. His government, while boasting of its role in the fall of military tutelage, behaved in even more authoritarian and anti-democratic ways than the Kemalist elite's statist modernisation projects had done. Consequently, authoritarian statism accompanied the restructuring of the local economy through neoliberal reforms. In this system, while a stronghold on the state's economy is a great obstacle to be overcome, the authoritarian hand of the state is essential for systematic privatisation and stabilisation of the economy in the face of inflation or crisis in the financial markets. In turn, the promotion of competitiveness and conceptualisation of extreme individualism in society, but also the repression of personal and collective freedom, have become increasingly common. Pierre Rosanvallon, the French intellectual and historian, describes the new phenomenon that replaced the ideological totalitarianism of the past century, as an "elected despotism"; other intellectuals prefer the term "neoliberal authoritarianism" (Rosanvallon 2006: 123; Bruff 2012: 114-116). In the case of Turkey, the rise of authoritarianism as a dominant state form has become the political feature of neoliberal transformation since the 1980 coup d'état.

On May 31, 2013, the people of Turkey, cowed by a history of coups d'état and civil authoritarianism, woke up to a nationwide revolt without knowing that it would be the biggest civil mass revolt of its history. The resistance was started on May 27 by a few dozen protestors occupying Gezi Park in the centre of Istanbul to protect the last piece of green space from turning into another superfluous shopping complex in the city. The protestors often only read their books in the park and planted trees to replace those ripped out by municipal workers as a way of demonstrating that they claim their commons. They kept watch day and night to stop the trees from being cut and construction bulldozers from digging. Sometimes they also would read to police as an act of passive protest to the armed forces of the state. Four days later, at dawn on May 31, police set protesters' tents on fire while people were sleeping in them and evicted them from the park using tear gas and water cannons excessively. That day, police brutality left more than two hundred people injured and more than a dozen badly wounded. By dusk, thousands of people had gathered in all the regions of the state: Ankara, Izmir, Mersin, Adana, Antakya, Izmit, 
Konya, and Manisa, to protest. Soon, the uprising spread to eighty-one cities in Turkey. The images of police violence upon peaceful environmentalists circulating through social media burst the bubble of long-standing silence. After Erdoğan dismissed and insulted the Gezi protestors as çapulcu "looters," they started to use the term proudly to identify themselves within the movement. Soon, protesters spread the concept of çapulcu and chapulling ("looting") on social media with caricatures, electronic posters, memes, cheeky videos and slogans.

This was in keeping with the observation of anthropologist Denis-Constant Martin (2001:

19): "The multiple modes of expression activated during celebrations and the highly symbolic nature of carnival practices offer ways and means to escape the censorship of verbal language and the exclusive logic of politics". The next day, on a wall in Istanbul, graffiti appeared that said "Every day I am chapulling"- and this slogan became an immediate, and humorous, public sensation. Individuals chose to be unified by the negative identity bequeathed by then Prime Minister Erdoğan. It should be noted that the word chapulling has now entered the English language; it means "fighting for one's rights" and many people added chapuller to their name on their social media profiles. This relentlessly subverted the conscious-making mechanism of the socially accepted identities while overturning the logic of a tyrant who uses degrading adjectives to identify the oppositional public just for the sake of exercising his power on them with a hope to demoralise them. On the other hand, such a humorous distortion of the word looter did not fit into the common perception of the activist identity as militant and destructive and, in fact, caused sympathy in local and global onlookers, instead of alienation and condemnation. Plural identities were not merged but rather unified under the new and inappropriate name looters given by the Prime Minister.

Associating with a name that subversively establishes a political agency created a feeling of identification with and belonging to the protest atmosphere for people from diverse backgrounds, beliefs, and socioeconomic levels who had never protested before. Douzinas (2013: 130) notes regarding this identification: "the relatively neutral term 'crowd' is accompanied by a number of negatively charged words which express fear and contempt towards a social category that acts outside accepted and tolerable norms". The sharp, witty and subversive humour of the çapulcu challenged the official language by mocking it, while questioning the existing ideological constructions of identity and community (Jefferson 1989: 159). This is a good example that shows how humour does not necessarily bring about political consensus, but has the capacity to subvert the hegemonic sense-making mechanism allowing for alternative logic and sensibility to thrive. Then, in turn, the protestors started to call Erdoğan dictator, and the signs and banners especially emphasised that they were fighting for democratic life. Erdoğan's recent law restricting alcohol consumption, his comments on abortion, his public speech about how many children a woman should bear, his censorship of the Internet and his threats to ban social media altogether were a few of his many recent intrusions into public life that stripped people of their dignity and interfered their daily life decisions. His commentary on social life was especially insulting to women; thus, it was not surprising that fifty-two percent of the protestors were women (Konda 2003).

The first couple of images of the peaceful protesters and some people in carnival costumes being wounded by the police attack in Gezi Park marked the sensory momentum in people's minds and ignited a mass protest, first at the somatic level, then on the streets. The psychological effect of the image of a woman in red, being gassed by police aiming at her face, was picked up by other people who had been suffocated in many other ways. And after this point, the chorus of voices screamed together: "We can't take it anymore! We need air!" Of course, this humane demand did not resonate well among the ruling party's cadre. Turkish governments, especially conservative ones, have always publicly displayed their discontent concerning political protests asking for democratic rights. Especially after the coup d'état in 1980, this reactionary and oppressive mentality about political protest became a suffocating reality of political life in Turkey 
(Temelkuran 2019). Erdoğan's response to this demand has been violent and oppressive, which terrorised some four million people involved in protests. However, this time, fear is confronted with humour and joy. Humour addresses the same issues as fear, but without dismissing them or escaping from them, thus strengthening our ability to confront them and then laugh our way to a healthier configuration of society (Avner 1988: 357).

For Gezi protestors, laughter was not only for fun and joy, but also a proud demonstration that they were more intelligent and more civilised than the governing body and the police forces. The young people, when taken into police custody, often smiled at the cameras with a proud gesture of victory. A smiling person, hands cuffed, being dragged by a dozen policepersons and knowing that mistreatment and even torture is waiting at the police station, has proved to be a subversive act against the extreme act of police violence. An image popularly posted on social media with a caption This is why we will win was of two young man taking a selfie when laughing at the heavily armed excessive police force. The slogan "disproportional intelligence against disproportional violence" that referred to the witty humour that accompanied the civil disobedience acts on the streets as graffiti on the walls and on telephone screens as the title of the humorous memes. It quickly became the motto that gave the protestors the kind of collective confidence that they needed.

\section{4. "Laughter is a revolutionary act"}

The Gezi Park protests started with people walking around in clown costumes, with all sorts of drummers playing, and people chanting and dancing in the park (Figure 1). This tactic symbolises the awareness that when confronted with humour and nonviolence, the hands of the establishment are tied. A bunch of clowns beaten by police, or people in fantasy costumes being tear-gassed, disturbs the image of any government. Nevertheless, soon after the joyous days, the images of a man in angel costume being beaten by government supporters and others being tear-gassed were shared on social media. Three days after the clowns' appearance in Gezi Park, on May $31^{\text {st }}, 2013$, Taksim Square resembled a war zone with gas bombs covering the crowds in a vast area, several TOMAs, (Toplumsal Olaylara Müdahale Arac1-Intervention Vehicle to Social Events), burning vehicles, and hundreds of injured people, while the mainstream Turkish TV channels were continuing their scheduled shows. People seeing those images impulsively flocked to the plazas of Istanbul, Izmir, Ankara, Hatay, and Eskisehir. Simultaneously, the physical protests were accompanied by visual protests in virtual and public spaces. 


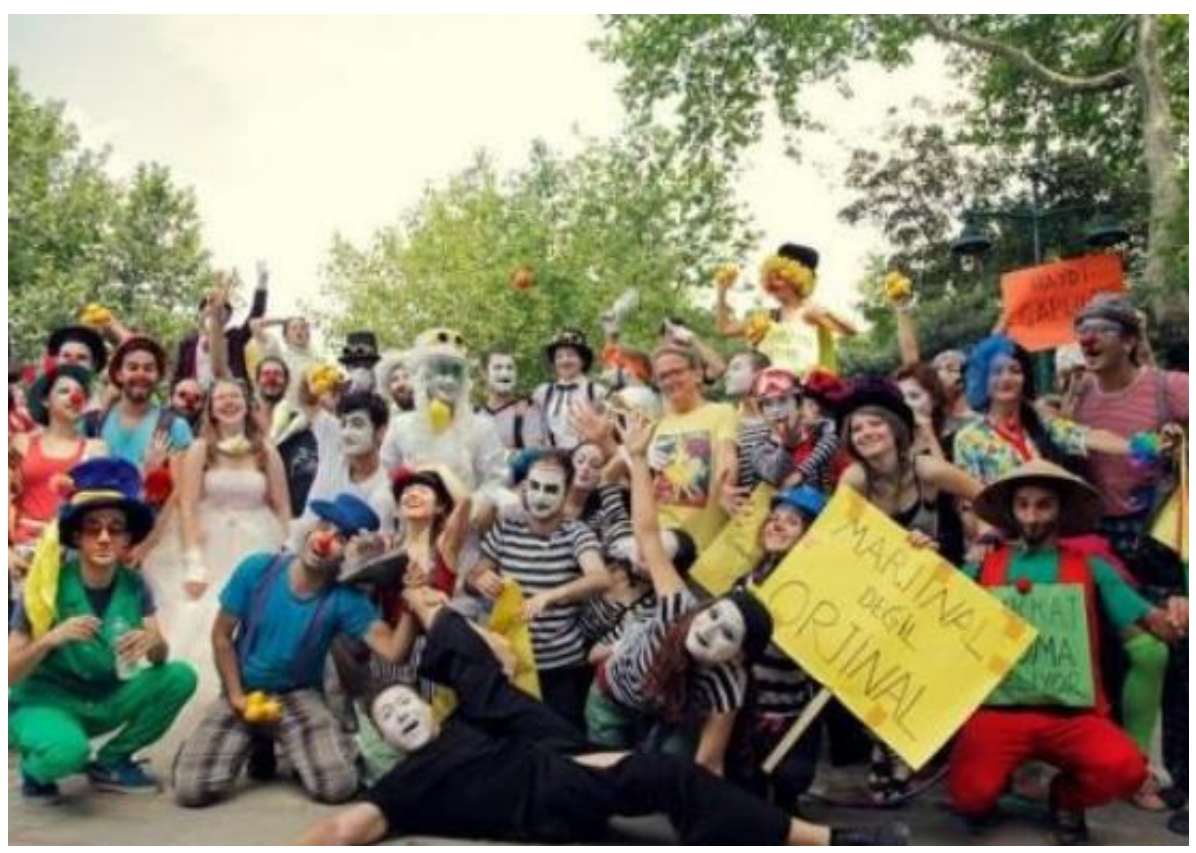

Figure 1. Clown group photo in Gezi Park. The banner says: "Original not Marginal" mocking Erdogan's words calling the protestors "a few marginals". Photograph taken by the author in Istanbul, Turkey, May 28, 2013.

During the most heated evening, the prestigious news channel CNN Türk showed a two-hour documentary of penguins in Antarctica and repeated it on the most violent nights of the uprising. Immediately after, the altered images of the penguin documentary on CNN Türk circulated on social media networks, with penguins in Antarctica as militant rebels and with the humorous caption "Antarctica is Resisting! Penguins: The problem is not the melting ice!" The following day, the visual and textual reaction to the brutality of the police intervention and negligence of the media were articulated in the symbol of the çapulcu penguins protesting censorship, authoritarianism, police violence and anti-democratic social life. The graffiti and murals of penguins representing Gezi protestors appeared everywhere in the city, from blank walls to billboards, bus-stop windows to pavements to declaring a visual war on the mainstream media. Facebook and Twitter pages were inundated with unprecedented creative activity centred on penguin memes. Perhaps that was the moment when visual resistance started to assume the character of carnival laughter. From that moment on, there was limitless creativity that turned the uprising into a carnivalesque rebellion as well.

Witty street art and graffiti were updated daily. Political cartoons and electronic posters criticised those in authority moment by moment on social media. The humorous disobedience did not only appear in two-dimensional media on the streets and virtual space. Satirical interventions and political street theatre were also spontaneously performed by the protestors and added another element to the carnival of resistance. For example, two dozen Turkish Airline workers performed a usual flight demonstration, with a comic twist:

Your life jacket is the fellow protestor next to you. In the case of emergency, physical aid, as well as morale and motivation, will be provided to you by your life jacket. In such cases, grab your life jacket, pull it toward you and hug it tightly. Afterward, laugh and cry together.

The types of political jokes directed at the ruler reflect both visual and textual representation of the oppressive ruling, which usually begins with comically "re-crowning" him as a foolish 
villain in order to disempower him. In Turkey, mocking Erdoğan publicly is punishable by a prison sentence; however, in the spontaneity and anonymity of the carnivalesque moment, Erdoğan's never smiling face appeared in different foolish depictions. Sometimes, mockery targeted his identification with Ottoman sultans (see Figure 2). Authority is sustained by the respect that is created by fear. Mocking authority damages this network of relationships and the fear of the ruler becomes weakened (Downing 2001:107).

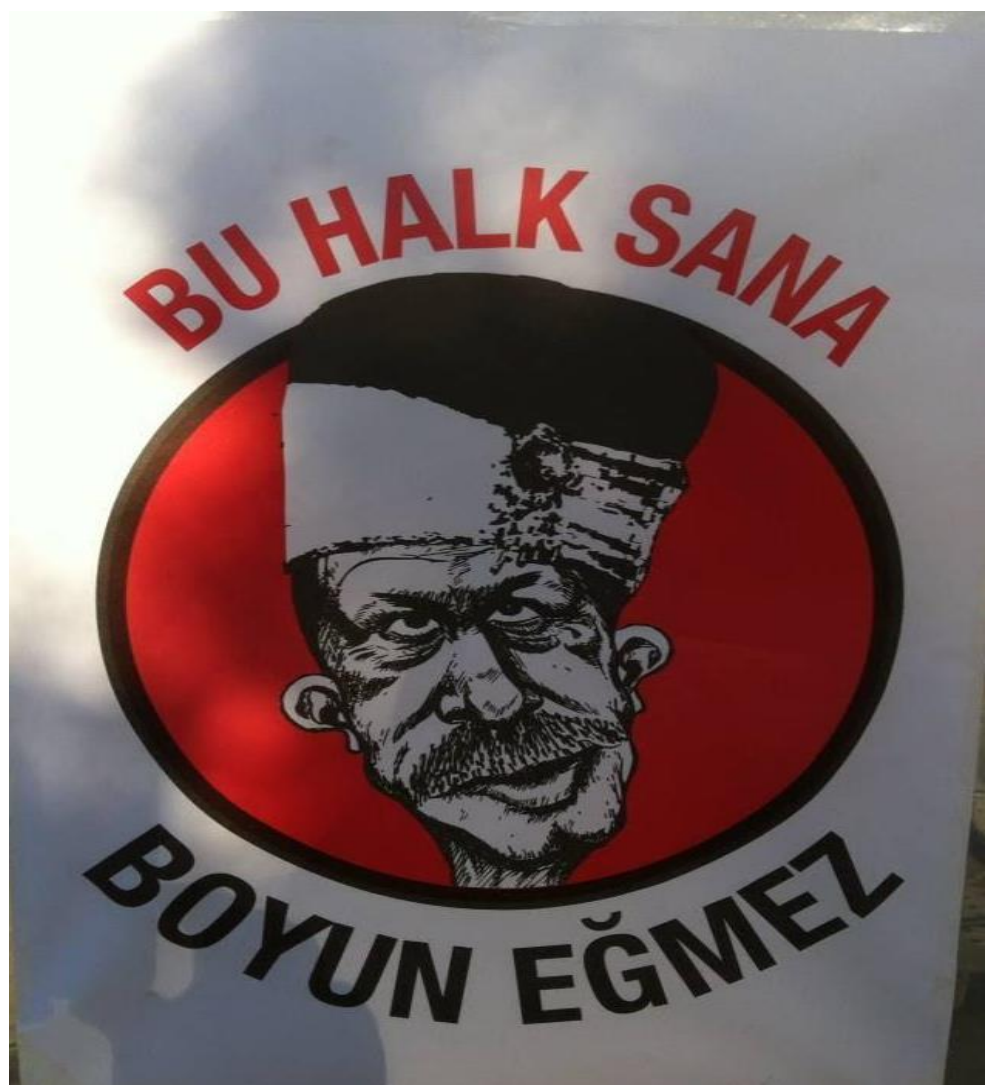

Figure 2. A poster with a satirical image of Prime Minister Recep Tayyip Erdoğan as a Sultan, hung at a bus stop in Istanbul. The caption reads "This public does not bow to you". Photograph taken by the author in Istanbul, Turkey, June 11, 2013.

During the most active days of the Gezi uprising, bowdlerized humour enhanced the carnivalesque spirit but also provided people with astonishing resilience and morale that empowered them in the face of the brutal political violence that killed young protestors. After a while, tear gas completely lost its ability to disperse crowds; on the contrary, humorous slogans such as This gas is fabulous, If we were afraid of gas we would not eat beans and We are gassed, it is not possible to stop were written on the walls, and people were chanting at police to gas them so that they could get going. Perrin Öğün Emre, Barış Çoban, Gülüm Şener observe that this humorous approach revolved especially around the satirical-masochist claims. For instance, the writers note more examples:

"Bu bibergazı bi harika dostum" [Dude, this tear gas is awesome!"], "Gaz bağımlılık yaptı panpa" [Now I'm a gas addict, bud], "Çilekli yok mu?" [Can I have strawberry-flavoured gas?], "Gazın mı bitti Abisi" [Ran out of gas, bro?], "Devlet Uyuma İsyancina Biber Sik" [State, wake up and spray pepper on your rebels], "haberim yokmuş gibi sik kanka" [Shoot it as if I wasn't aware of it, dude], "Oha resmen gazatmış" [Jeez, you've really gassed!], "Biber gazı sıkmanıza gerek yoktu bayım, zaten yeterince duygusal çocukları !" [Mister, there was no need for teargas, we guys are already emotional enough], "Gazlar Meksikadan mı hacı?" [Does the gas come from Mexico, man?], "Just in Biber" 
[Just in Pepper - a reference to Justin Bieber in which rhyme was intended between "Bieber" and "Biber" which means "Pepper"] (Öğün et al. 2014:10).

On the other hand, Gezi protestors also used witty slogans from the May 1968 riots in Paris. The most commonly used among them were the slogans: Yasaklamak yasaktir ("It is forbidden to forbid!") and Siir sokakta ("Poetry is in the street"). This joyous and poetic ambiance helped the protestors to pass the threshold of fear that for decades - especially with the memories of the bloody military coups in 1971 and 1980 - has been the most powerful weapon of political oppression of the state in Turkey. This time, the lack of fear ignited the vitality and creativity in the protestors that became the lifeforce of the movement. The slogan Laughter is a revolutionary act was borrowed from the young radical revolutionaries of the 1960s and became one of the mantras of the protests.

Laughter is effective in creating non-hierarchical social relations because it is affective. The aesthetic experience created by laughing together with strangers, in an environment that could be life-threatening, has a transformative effect on individuals in terms of how they perceive others and even how they perceive the world around them (Hart 2007; Scholl 2010; Tunali 2018). Hart notes: "The impact of humour (brought about by laughing with one another) can strengthen and forge long-term responses like feelings of affection, solidarity, and loyalty among activists" (Hart 2007: 2). Humour does more than express a vocabulary of resistance in repressive and nondemocratic contexts: it creates unusual social bonds that can also create a form of "dark knowledge and experience that underlie the parody" (Bernal 2013: 308). As such, humour becomes a clever and highly engaging element confronting the heavy-handed control apparatuses.

The anonymous and ever-flowing humour created a heartfelt communication and unity among the protestors that helped constitute an alternative life during the two-week occupation of Gezi Park. This not only made the resistance discursively tangible, but it also solidified the momentum of the protests (Tunali 2018). During the occupation of Gezi Park, leaving their quotidian existence behind, people experienced a harmonious and autonomous union and the renewed way of life in the absence of the state. Free stores called "revolutionary markets", libraries, public bathrooms and showers, a medical clinic tent (where even minor surgeries were performed), media production zones, discussion platforms, cultural events, a podium for music and art performances, a Gezi museum (where photographs, posters, and other objects of resistance were being exhibited), and food tents were established and run with mutual aid. It was a large utopian camp where horizontal dimensions of the collective organisation and self-government determined life. This spontaneous political formation is called the "Commune" (Dardot \& Laval 2019:7). The social groups, which are historically antagonistic to each other-those that could never tolerate each other's existence in public spaces, such as the football hooligans and gays, the Kemalist nationalists and Kurds, the Sunnis and Alawites (a religious minority that is arguably a branch of Islam marginalised since the reign of Ottoman Empire) - listened to one another and acknowledged each other's views in a democratic way (Örs \& Turan 2015). Walton (2015: 51) remarks: "Gezi was defined by a conglomeration of multiple political identities. What linked the protestors was not an identity, but a novel, emphatic practice of citizenship, a public performativity". The egalitarian life of the commune and this togetherness have come to be known as "the Gezi spirit". According to Temelkuran, this spirit was created in the humorous atmosphere of the carnival of resistance and in turn, it fed a sense of brotherhood and sisterhood that brought out the best in people (Temelkuran 2019: 223). Sociologist Meyda Yeğenoğlu, in her article "Smells like Gezi Spirit," writes about the relation of that carnivalesque spirit to the democratic becoming of the protesting crowd:

By remaining indifferent to democracy as a political system that is instituted in a top-down fashion, they are now accomplishing a carnivalesque displacement of existing enmities. But, as Asad's analysis reminds us, it will become clear in the coming period whether the democratic sensibility that 
flourished in the park will have the power to permeate and determine the state's politics or whether the state's sovereign politics of democracy will undermine the democratic sensibility that has emerged through the protests (Yeğenoğlu 2013: 2-3).

\section{Conclusion: humour as aesthetics of solidarity}

The new generation of activists has been joining forces with artists and other imaginative people to make protests creative, inspirational and joyful, not only to attract attention of the masses and ensure the continuation of the protests, but also to insert an alternative way of being a political subject before steel-faced police and politicians. This inevitably becomes an aesthetico-political way of becoming a caring, gentle, attentive, kind and concerned human while confronting authoritarianism and intolerance. Of course, the activist avant-garde has not always embraced humour or other carnivalesque elements in political protests. In her study of the role of humour in autonomous social movement groups in Madrid, Christina Fominaya noted that some activists with a traditional background expressed their discomfort because "humour detracted from the political weight of these actions, making them 'light' versions of what should have been more confrontational acts" (Fominaya 2007: 256). Hence, four years after Fominaya published her article, we observed in the occupation of the Plaza del Sol that this view has been less and less putative among the activists in Spain. Even Hannah Arendt's critics thought that her humorous style lacked the gravity expected from material dealing with the Holocaust. However, this was a conscious part of Arendt's political rhetoric; she thought that "the greatest enemy of authority, therefore, is contempt, and the surest way to undermine it is laughter" (Arendt 1970: 45). Arendt theorised joy as political sensibility against the normalisation of authoritarianism (Arendt 1970, 1972). What is also important in Arendt's analysis of totalitarianism is that it is not outside of collective thought; on the contrary, it is the radical outcome of thinking together but in the singular form, and thus creates a culture of consent (Griffin 1991).

Acknowledging the discussion of humour as a powerful communication tool in social movements, this paper proposed that the collective experience of humour is an aesthetic experience; during occupations, marches, sit-ins, protests, and clashes with police, it creates a social impetus that could unleash a regenerative force in the society. It was in the temporary suspension of everyday life and the disordering of power by the carnivalesque that provided instances for people to cross the threshold of fear and recuperate their voice. Carnival aesthetics created "spaces of experience" where imagination, creativity, and pleasure are embraced and celebrated as integral to political engagement to "permit actors to live according to their own principles, to knit different social relations and to express their subjectivity" (Pleyers 2010: 39). Such experience has the power to reconfigure established social relations, norms and beliefs as well as to consolidate solidarities, not only among those protestors on the streets and squares but also with those who stayed at home. The humorous carnival of the recent urban social uprisings was not just a festive celebration of non-hierarchical activism, togetherness of adverse political groups and individuals, experimenting and experiencing an-other world order; it was also a difficult and laborious undertaking where people engaged in various speech and creative practices, at the same time facing the attacks of the heavily-militarised police any moment. Despite this constant threat, protestors remained joyful and blissful, thus positioning themselves as more civilised and sophisticated compared to the police and the government, whose only resort was violence. This civility is not so much about the superiority against barbarism as a reflective mode of keeping the political space open, dignified, creative and active, allowing the process of recomposition of new subjectivities and a new form of life to take place. As Paolo Virno writes, humour is an "action that undermines and contradicts the prevalent belief-system of a community, thus revealing the transformability of the contemporary form of life" (Virno 2007: 129). Bringing the humorous aesthetics to social movement research adds another dimension to the relationship 
between emotions and perception in social movements because it deals with the questions of affect and becoming political subjects.

The humour of the protesting crowd is a distinct aesthetic experience that opens up avenues for democratic relationships and re-transformed subjectivities. Laughter itself is not a political action, but a force that charges the collective with an indeterminable amount of resilience and confidence. As Temelkuran emphasised, our transformation into passive audiences who do not engage in political activity against the dominant economic and political structures has been accelerated by the rise of conservativism and right-wing populism. The politics of aesthetics in Gezi was the realization that the public was not powerless, indifferent or depotentialised, and that they have a choice (Taşkale 2014). This paper showed that humour works as the antidote to hegemonic-sense-making mechanisms, the greyness of our collective thinking and the reluctance to use our political subjectivity. The satire of the upside-down world, the joy of the rebellious spirit and the spontaneous laughter experienced collectively create moments of liberation from the social codes of domination (Scott 1990). Hardt \& Negri note on that the

[m]ovements of revolt and rebellion, we find, provide us the means not only to refuse the repressive regimes under which these subjective figures suffer but also to invert these subjectivities in figures of power. They discover, in other words, new forms of independence and security on economic as well as social and communicational terrains, which together create the potential to throw off systems of political representation and assert their own powers of democratic action (Hardt \& Negri 2012: “Opening").

The humorous activism is aesthetically and collectively developed as a tactical response to the ruling elite. Humour is meant to shake, inspire, and move, solidifying the lived imaginary of the movement where new subjectivities are free to emerge. Although those moments are temporary, what remains is a new political and aesthetic discourse and a new set of political habits that carry the potential to create other bottom-up political practices in the current political Ice Age. When resurgent fundamentalisms, nationalisms and widespread anti-immigration feelings are reshaping the social climate in a conservative and dangerous fashion, it is imperative to find out who we are as political subjects and how to activate our political agency.

\section{Acknowledgements}

This article was written during my Le Studium/ Marie-Sklodowska Curie Fellowship 2018-2019. I thank Le Studium Institute of Advanced Studies Val de Loire for their institutional and financial support. I also thank the anonymous peer reviewers for their comments and Dr. Villy Tsakona for her valuable feedback.

\section{References}

Arendt, H. (1972). Crises of the Republic: Lying in Politics; Civil Disobedience; On Violence; Thoughts on Politics and Revolution. Houghton: Mifflin Harcourt.

Arendt, H. (1970). On Violence. Harcourt Brace Javanovich: New York.

Bakhtin, M. (1984.) Rabelais and His World. Trans. H. Iswolsky. Bloomington: Indiana University Press.

Bakhtin, M. 2002. Karnavaldan Romana. İstanbul: Ayrınt1.

Bernal, Victoria. (2013). 'Please forget democracy and justice: Eritrean politics and the powers of humor.' American Ethnologist 40 (2), pp. 300-309. 
Bey, H. (1985). TAZ: The Temporary Autonomous Zone, Ontological Anarchy, Poetic Terrorism. New York, Autonomedia.

Bruff, I. (2012). 'Authoritarian neoliberalism, the Occupy Movements, and IPE.' Journal of Critical Globalization Studies 5, pp. 114-116.

Bruner, L. M. (2005). 'Carnivalesque protest and the humorless state.' Text and Performance Quarterly 25 (2), pp. 136-155.

Bogad. L.M. (2010). 'Carnivals against capital. Radical clowning and the global justice movement.' Sociology. $\quad$ https://www.semanticscholar.org/paper/Carnivals-againstcapital\%3A-radical-clowning-and-theBogad/e563cd6bede98cbd1c1b478345c03489d868c2f4. Accessed March 12, 2020.

Charny, I. W. (2006). Fascism and Democracy in the Human Mind: A Bridge Between Mind and Society. Lincoln: University of Nebraska Press.

Davies C. (2007). 'Humor and protest: jokes under communism' in Hart, M. \& Bos, D. (eds.) Humor and Social Protest. Cambridge University Press, pp. 291-309.

Dardot, P. \& Laval, C. Common: On Revolution in the Twenty-First Century. London: Bloomsbury.

Downing, J. D.H. (2001). Radical Media: Rebellious Communication and Social Movements. Thousand Oaks, CA: Sage Publications.

Douzinas, C.. (2013). Philosophy and Resistance in the Crisis: Greece and the Future of Europe. Cambridge, UK: Polity Press.

Eagleton, T. (2009 [1981]). Walter Benjamin, or Towards a Revolutionary Criticism. New York: Verso Books.

Fominaya, C. (2007). 'The role of humour in the process of collective identity formation in autonomous social movement groups in contemporary Madrid', International Review of Social History, Humour and Social Protest 52, pp. 243-258.

Furedi, F. (2019). 'Clown world: Extinction Rebellion is a carnival for middle classes who love to dress up as activists.' October 7, 2019. https://www.rt.com/op-ed/470384-extinctionrebellion-protest-performance/. Accessed November 12, 2019.

Georgalidou, M. (2011). 'Stop caressing the ears of the hooded': Political humour in times of conflict,' in Tsakona, V. \& Popa, D. E. (eds.), Studies in Political Humour: In between Political Critique and Public Entertainment. Amsterdam \& Philadelphia: John Benjamins, pp. 83-107.

Graeber, D. (2007). 'On the phenomenology of giant puppets: broken windows, imaginary jars of urine, and the cosmological role of the police in American culture" in Graeber, D. (ed.), Possibilities: Essays on Hierarchy, Rebellion and Desire, Oakland, CA: AK Press.

Graeber, D. (2010). "The new anarchists." New Left Review 13. Accessed October 10, 2011. http://newleftreview.org/II/13/david-graeber-the-new-anarchists.

Griffin, R. (1991) The Nature of Fascism. New York: St. Martin's Press.

Griffin, R. (2006). "The breath of the possible" in Biddle, E., Graeber, D. \& Shukaitis, S.(eds.). Constituent Imagination:, Militant Investigation, Collective Theorizations, Oakland, CA: AK Press.

Grindon, G. (2004). 'Carnival against capital: a comparison of Bakhtin, Vaneigem and Bey', Anarchist Studies 12, pp. 147-161.

Gordon, M. (2012). 'Exploring the relationship between humor and aesthetic experience.' The Journal of Aesthetic Education, 46 (1), pp. 110-121.

Guardian (2019). '’Older generations can't understand': XR Youth on Being heard.' Accessed 12 December 2019.

https://www.theguardian.com/environment/2019/oct/19/older-generations-will-neverunderstand-extinction-rebellion-xr-youth-on-being-heard. 
Harvey, D. (1990). The Condition of Postmodernity: An Enquiry into the Origins of Cultural Change. Cambridge, Mass.: Blackwell.

Hart, M. (2007). Humor and Social Protest: An Introduction. International Review of Social $\begin{array}{llll}\text { History. } & \text { Accessed } & \text { November } & 13 .\end{array}$ http://journals.cambridge.org/action/displayJournal?jid=ISH.

Hart, M. \& Bos, D.. (2007). Humor and Social Protest. Cambridge University Press.

Hardt, M. \& Negri A. (2012). Declaration. Accessed 12 January 2013.

https://antonionegriinenglish.files.wordpress.com/2012/05/93152857-hardt-negri-declaration2012.pdf

Haugerud, A. (2012). 'Satire and dissent in the age of billionaires.' Social Research 79 (1), pp. $145-168$

Holloway, J. (2010). Crack Capitalism. London: Pluto Press.

Holloway, J. (2002). Change the World without Taking Power. London: Pluto Press.

Kaptan, Y. (2016). 'Laugh and resist! Humor and satire use in the Gezi resistance movement.' Perspectives on Global Development and Technology. Vol. 15. Accessed December 23, 2017. https://brill.com/view/journals/pgdt/15/5/article-p567_8.xml.

Kahraman, H.B. Postmodernite ile Modernite Arasinda Turkiye: 1980 Sonrası Zihinsel, Toplumsal, Siyasal Dönüşüm. Istanbul: Agora Kitaplığı, 2007.

Konda (2014), Gezi Raporu: Toplumun 'Gezi Parki Olaylari' Algisi. Gezi Parkindkailer Kimlerdi? Konda Arastirma Ve Danismanlik. https://konda.com.tr/wpcontent/uploads/2017/02/KONDA_GeziRaporu2014.pdf. Accessed 24 January 2018.

Konda. Gezi Parkı Araştırması (2014). Accessed August 14, 2013, www.konda.com.tr.

Kutz-Flamenbaum, R.V. (2014). 'Humor and social movements.' Sociology Compass 8 (3), pp. 294-304.

Mahiye, S. D. (2016). 'Down with some things! The politics of humor and humor as politics in Turkey's Gezi protests', Etnofoor 28 (1), pp. 11-34.

Martin, D.-C. (2001). 'Politics behind the mask: Studying contemporary carnivals in political perspective.' Questions de Recherche/Research in Question 2, pp. 16-25.

Mersal, I. (2011). 'Revolutionary humor.' Globalizations 8, pp. 669-674.

Morreall, J. (1981). 'Humor and aesthetic education.' Journal of Aesthetic Education 15 (1), pp. 55-70.

Mulkay, M. (1988). On Humor Its Nature and Its Place in Society. Cambridge, Polity Press.

Moy, P., Xenos, M. A., \& Hess, V. K. (2006). 'Priming effects of late-night comedy'. International Journal of Public Opinion Research 18, pp. 198-210.

Notes from Nowhere, ed. (2003). We Are Everywhere: The Irresistible Rise of Global Anticapitalism. London and New York: Verso.

Örs, I. R. and Turan, Ö.. (2015). 'The manner of contention: the pluralism at Gezi.' Philosophy \& Social Criticism 41 (4-5), pp. 453-463.

Perrin, E. Ö, Çoban B. \& Şener, G. (2013). 'Humorous form of protest: disproportionate use of intelligence in Gezi Park's resistance." Unpublished paper presented at the Conference Political Science in the 21st Century: New Opportunities and Impasses Theorising and Experiencing Politics October 31 to November 2, 2013. Istanbul, Turkey.

Powell, C., and Paton, G.E.C. eds. (1988). Humour in Society: Resistance and Control. New York: St. Martin's Press.

Rosanvallon, P.. (2006). Democracy Past and Future, ed. by S. Moyn. New York: Columbia University Press.

Scott, J. C. (1990). Domination and the Art of Resistance. New Haven. Yale University Press.

Sørensen, M. J. (2008). 'Humor as a serious strategy of nonviolent resistance to oppression.' Peace \& Change 33, pp. 167-190. 
Soner, C. (2020). Erdogan's Empire: Turkey and the Politics of the Middle East, New York: Tauris.

Taș, H.. (2015). 'Turkey -From Tutelery to Delegative Democracy', Third World Quarterly 36, pp. 776-791.

Taşkale, A. R. (2014). “Gezi revolt: critique, courage.' Society and Space. Accessed

February 11, 2019. http://societyandspace.com/material/discussion-forum/forum-onturkey/taskale/.

Temelkuran, E. (2019). How to Lose a Country: The 7 Steps from Democracy to Dictatorship, Sydney: Harper Collins.

Tsakona, V. \& Popa, D. E. (2011a). 'Humour in politics and the politics of humour: An introduction,' in Tsakona, V. \& Popa, D. E. (eds.), Studies in Political Humour: In between Political Critique and Public Entertainment. Amsterdam \& Philadelphia: John Benjamins, pp. 1-30.

Tunal1, T., (2018), 'Art of resistance: carnival aesthetics and the Gezi street protests', ASAP: Journal of the Association for the Study of the Arts of the Present (Special Issue: Rules of Engagement: Art, Process, Protest) 3 (2), pp. 377-399.

Wallerstein, I. (2013). 'Uprisings here, there, and everywhere.' Fernand Braudel Center: Commentaries No. 356. Accessed July 1, 2013, http://www2.binghamton.edu/fbc/commentaries/archive-2013/356en.htm.

Žižek, S. (2013). 'Trouble in Paradise,' London Review of Books 35/14 (2013), pp. 11-12.

Vaneigem, R. (1994) The Revolution of Everyday Life. London: Left Bank Books.

Virno, P. (2007). 'Multitude between innovation and negation.' Semiotext(e), Los Angeles, CA.

Yeğenoğlu, M. (2013), 'Smells like Gezi spirit: democratic sensibilities and carnivalesque politics in Turkey,' Radical Philosophy 182, pp. 2-3.

Young, D. G. (2017), 'Theories and effects of political humour: Discounting cues, gateways, and $\begin{array}{llll}\text { the } & \text { impact } & \text { incongruities'. }\end{array}$ https://www.oxfordhandbooks.com/view/10.1093/oxfordhb/9780199793471.001.0001/oxfo rdhb-9780199793471-e-29?rskey=NBL29e\&result=2 Accessed. March 12, 2020.

Ziv, A. (1988) "Humor as a social corrective," in Behrens, L. \& Rosen, L.J.(eds.), Writing and Reading Across the Curriculum Glenview, IL: Scott, Foresman and Company. 